\title{
Policy Recommendations to Improve the Quality of Life for LGBT Older Adults
}

\author{
Alex Redcay ${ }^{1}$ (D) - Sheila McMahon ${ }^{2}$ - Valentina Hollinger ${ }^{1} \cdot$ Heather L. Mabry-Kourt ${ }^{1} \cdot$ Tyler B. Cook $^{1}$ \\ Published online: 11 July 2019 \\ (C) Springer Nature Switzerland AG 2019
}

\begin{abstract}
This article explores the increased vulnerability of older lesbian, gay, bisexual, and transgender (LGBT) adults and their needs. Older LGBT adults lack legal protection, which leads to higher rates of discrimination in the work environment, living arrangements, and services. The impact of discrimination against older LGBT adults results in an elevated rate of physical and psychological consequences when compared to the general older population. A brief overview of legal precedence pertaining to the LGBT community is provided, and the needs of older LGBT adults are identified. Social work practice and policy recommendations are highlighted to address identified needs and improve the quality of life for older LGBT adults. A human rights framework is applied to inform all practice and policy recommendations to ensure basic human rights are met, as outlined in the Universal Declaration of Human Rights. The role of the social worker in addressing the needs of older LGBT adults is discussed, as well.
\end{abstract}

Keywords Older LGBT · Human rights · Discrimination · Policy

\section{Introduction}

Knowledge about the needs of lesbian, gay, bisexual, and transgender (LGBTQ) older adults is limited. To date, little research has been conducted to address the needs of older LGBT adults through a human rights framework in practice and policy and when identifying the role of the social worker in meeting those needs (Committee on Lesbian 2011).

The Universal Declaration of Human Rights (UDHR) was written and adopted by the United Nations (UN) in 1948. Since its adoption by the General Assembly, the UN promised only to "promote" and "encourage respect for" human rights, assigning moral value without giving the UDHR any legal enforcement tools. In 1966, the General Assembly agreed upon an International Bill of Human Rights, composed of the UDHR and its two main "implementing" treaties: The International Covenant on Civil and Political Rights (ICCPR) and the International Covenant on Economic, Social and Cultural

Alex Redcay

Alex.Redcay@millersville.edu

1 Millersville University, P.O. Box 1002, Millersville, PA 17551-0302, USA

2 Barry University, 11300 NE 2nd Ave, Miami Shores, FL 33161, USA
Rights (ICESCR). While the International Bill of Human Rights was signed by many of the world's most powerful international leaders, including US President Jimmy Carter, the USA has supported only some of the UDHR's 30 articles outlining the international standard for human rights. Many of the articles correspond to US Constitutional Amendments (The Advocates for Human Rights, 2018); however, articles 22 through 26, which describe equal access to economic and social rights, such as "the right of everyone to an adequate standard of living - including food, housing, healthcare, social services and basic financial security" - have been rejected by the USA as basic rights and are subsequently not subject to legal enforcement (Parsons 2018).

Within the context of the social work profession, our responsibilities for the human dignity of all persons, especially vulnerable populations, including persons who are LGBT and aging. The social work Code of Ethics, put forth by the US National Association of Social Workers (NASW), not only requires that social workers should be culturally competent, but also respect the dignity of persons, and work to end discrimination in all of its forms (National Association of Social Workers 2018). Additionally, NASW has produced policy statements that clearly articulate the value of persons who are LGBT, including the right to marry (Lennon-Dearing and Delavega 2015). Therefore, beyond the limitations of the UDHR, social workers as a profession have made an 
explicit commitment to care for the needs of persons who are LGBT and elderly. This commitment is critical, as many LGBT adults who are aging need competent, responsive care.

It is estimated that in the USA, 2.4 million (2.4\%) adults above the age of 50 identify as LGB (Fredriksen-Goldsen et al. 2014a), while between 1.2 million and 2.8 million adults over 65 identify as transgender (Witten 2016). Together, the LBGT adult population in the USA is projected to exceed over 5 million by 2030 (Fredriksen-Goldsen and Espinoza 2015). Healthy People 2020, a US data collection service that provides science-based, 10-year objectives for improving the health of all Americans, recognizes the additional health barriers faced by aging LGBT individuals, including isolation, the lack of appropriate services, and lack of culturally competent providers (Healthy People 2020). Citing social, economic, and health disparities, LGBT individuals were identified for the first time as a US national health priority and an atrisk population (Emlet 2016).

\section{Overview}

The general older population face several challenges and concerns as they age (Christensen et al. 2009). These can include, but are not limited to, loss of physical and mental capacities, social isolation, abuse, poor mental health, and the negative impacts of discrimination in the form of ageism. As a result, older adults are classified as a vulnerable population (Paula et al. 2017). LGBT older adults are often dismissed and overlooked, despite being disproportionately affected by the same challenges the general older adult population encounters (Thomeer et al. 2018). Furthermore, the LGBT older adult population faces additional barriers because of their sexual orientation and identity (Erdley et al. 2014; Thomeer et al. 2018).

\section{Physical Health with Health disparities and LGBT Elders For} example, LGBT adults are more likely to report more longterm negative health conditions compared to heterosexuals of the same age (Gonzales et al. 2016). They experience greater levels of obesity, high blood pressure, cardiovascular disease, diabetes, disability, and general poor health (FredriksenGoldsen et al. 2012).

Mental Health and LGBT Elders Older LGBT adults are also at increased risk for psychological distress, isolation (i.e., living alone), anxiety, depression, and suicidal thoughts (Emlet 2016; Fredriksen-Goldsen and Espinoza 2015). These disparities intensify with age and are made worse due to social isolation, and the increased likelihood of abuse by caretakers (Fredriksen-Goldsen and Espinoza 2015; Sokan and Teaster 2016). LGBT elders are also less likely to seek assistance in abusive situations due to fears of discrimination on the basis of sexual orientation (Sokan and Teaster 2016).
Health Disparities and LGBT Elders In general, older LGBT adults are at a higher risk of health disparities in comparison to their similarly aged heterosexual counterparts due to a confluence of social factors (Fredriksen-Goldsen and Espinoza 2015; Gonzales et al. 2016). For example, research has found that LGBT elders who are also Black or African American are at greater risk for a range of poor health outcomes including chronic illnesses, HIV/AIDS, depression, and substance abuse (Harley 2016). Despite being disproportionately impacted by health disparities, LGBT elders of color are often absent from policy discussions about their own well-being (Auldridge and Espinoza 2013; Harley 2016). Rates of poverty for LGBT older adults also increase with age (Emlet 2016). Nearly a third of the LGBT older adults lived at or under the federal poverty level and a quarter experienced financial difficulty when attempting to access health services (Emlet 2016).

Most LGBT older adults grew up when the marginalization and stigmatization of sexual minorities was more prevalent than it is today (Kim et al. 2017). Because many LGBT older adults are more likely to have been impacted by social stigma, victimization, and discrimination, they are more likely to experience poor health and depression symptoms (Emlet 2016). Article 2 of the UDHR promises the right to Freedom from Discrimination (UDHR 1948). In addition, the older LGBT population grew up in environments that were less accepting and supportive than those experienced by younger LGBT populations (Committee on Lesbian, Gay, Bisexual, and Transgender Health Issues and Research Gaps and Opportunities 2011). Consequently, the discrimination and marginalization that LGBT older adults have faced may have prevented them from building support systems and social ties, which can lead to elevated risks of isolation and poor mental health (Kim et al. 2017). Additionally, the current population of LGBT older adults lived through the HIV/AIDS pandemic, and many have lost supportive social connections, while the current generation lives with a very different perspective of HIV/AIDS as a familiar, yet survivable fact of life (Russell and Bohan 2005). Due to their lack of social networks, community correctness, and biological family ties, many LGBT older adults rely heavily on peer-based support (Kim et al. 2017).

\section{Generational Differences Among LGBT Persons}

Russell and Bohan (2005) discuss the vast differences between today's LGBT youth and older LGBT adults. Even though homophobia and heterosexism are still pervasive within our culture, the degree to which they affect the lives of youth has diminished in intensity and frequency, due in large part to the historical advocacy and political action of older LGBT adults. Many LGBT youth have not experienced the negative stories told by LGBT elders who suffered before them, although youth do admit to being "involved with the problems people talk about in surveys" (Russell and Bohan 
2005, page 5). Some activists believe that the "residual fears and pain" of LGBT older adults may contribute to the magnification of the actual challenges faced by LGBT youth (Russell and Bohan 2005). Another difference between LGBT youth and older adults is the current generation's awareness of, and resources for, effectively dealing with internalized homophobia are much more robust than for previous generations of LGBT individuals (Russell and Bohan 2005). Additionally, being less familiar with, and possibly less affected by, the very real fears, barriers, violence, ostracism, social isolation and family rejection that were part and parcel of the foundation of older LGBT adults' identity, LGBT youth often fearlessly forge new pathways toward equal human rights for all. Cross generational sharing of past, present, and future LGBT culture can strengthen the community (Russell and Bohan 2005). Finally, social workers of all generations, sexual orientations, and gender identities can engage in this important intergenerational dialogue by learning about the history of LGBT persons in the USA (such as the "Lavender Scare" during the McCarthy era) and being prepared to address the increased likelihood of bullying and interpersonal aggression faced by LGBT elders, especially those LGBT elder clients living in communal settings such as nursing homes (Bonifas 2016).

\section{Impact of Discrimination}

Though research has found that the mental health of LGBT individuals has improved in states that have passed LGBTfriendly legislation, many LGBT older adults may still feel excluded from participating fully in societal institutions due to microaggressions and heterosexist assumptions (Fredriksen-Goldsen and Espinoza 2015). For example, during an intake, the social worker doing the intake may ask if the client is married and assume that they are married to a person with a different gender. For the elder, this may communicate that the agency has limited training in LGBT issues and may be unfriendly so the client may conceal their sexual orientation. Research has found that while social workers tend to behave more positively toward persons who are LGBT, there is not uniform support for the LGBT community among social work practitioners and social work students (Chonody and Smith 2013). This is troubling because research has found that discrimination and societal exclusion on the basis of sexual orientation or gender identity can negatively impact an individual's income, physical and mental health, and life expectancy (Fredriksen-Goldsen and Espinoza 2015).

\section{Marriage}

Moreover, structural level discrimination against LGBT persons can adversely impact health (Hatzenbuehler et al. 2014). For example, the lack of nationwide same-sex marriage rights in the USA may have led to increased social isolation in LGBT older adults (Kim et al. 2017). In Obergefell v. Hodges, 2015, the Supreme Court ruled that all states must recognize legal same-sex marriages (marriage legalized based on state of celebration), granting married same-sex couples access to Medicaid spend-downs, Social Security survivor benefits, bereavement leave, and tax exemptions upon inheritance of jointly owned real estate and personal property (Department of Health and Human Services 2015; Fredriksen-Goldsen 2016), and Article 16 of the UDHR promises the Right to Marriage and Family (UDHR 1948).

Before that, in United States v. Windsor 2013, the Supreme Court extended several federal benefits to LGBT adults in legal marriages. Also in 2013, legislation was signed by the Obama administration that added sexual orientation and gender identity to Executive Order 11246. Signed by President Lyndon B. Johnson in 1965, this order disallowed government contractors from discriminating on the basis of race, religion, sex, or national origin (Fredriksen-Goldsen and Espinoza 2015). Furthermore, the Equality Act, introduced in Congress in 2017 to amend the Civil Rights Act of 1964, included strong protections against discrimination based on sexual orientation or gender identity (Fredriksen-Goldsen 2016).

\section{Support Services for LGBT Elders}

Yet, through ongoing discrimination and a lack of specifically directed outreach, LGBT adults are less likely to utilize aging services and programs, even when available (LGBT Elder Initiative 2017). Out of fear of discrimination, many LGBT adults do not access health and other support services (Fredriksen-Goldsen and Espinoza 2015). For example, many LGBT patients have been denied medical care, refused care from hospital ward nurses, and abused in nursing homes and senior centers (Cartwright et al. 2012; Hash and Netting 2007; Witten 2016). Because rates of chronic illness and disability are more common among LGBT elders than the general aging population (Harley, 2015), access to aging-related social services is critical to maintaining health and dignity.

Relatedly, LGBT older adults have not formalized end-oflife documents (Thomeer et al. 2018; Witten 2016). This should mobilize community organizations serving the LGBT population to offer low- or no-cost legal assistance to LGBT older adults, supporting their necessary later-life legal decisions, and bolstering legal protections against potential discrimination or post-death backlash (Witten 2016). Long-term planning and discussions need to be implemented with younger and middle-aged LGBT individuals, as well, so that their later-life legal needs and decisions can be formally established and legally documented (Witten 2016). Because traditional familiar support systems may not be accessible for LGBT elders, social workers and other helping professionals play a 
critical role in ensuring that clients have the option to engage in long-term planning, as well as access to resources such as safe and affordable housing.

\section{Senior Housing}

Forty-eight percent of older same-sex couples and a quarter of transgender older adults face discrimination when they apply for senior housing, and one in six (17\%) LGBT older adults are concerned they will be discriminated against if others in an assisted-living community discover their sexual orientation or gender identity (SAGE 2015). Justice in Aging, with several other agencies, expanding on their groundbreaking 2010 report, conducted an online survey to better understand the current challenges faced by LGBT older adults in long-term care facilities (Justice in Aging 2015). Out of the 769 individuals who took the survey, 284 identified as LGBT older adults. In total, of the 328 respondents (43\%) who experienced maltreatment from staff, 124 were LGBT older adults. Only $22 \%$ of LGBT respondents felt they could be honest with facility staff regarding their gender identity and sexual orientation. Eighty percent of the respondents reported that they, a family member, or a partner had experienced staff refusing to refer to a patient by his or her preferred name and/or pronoun. Forty-six percent of the LGBT respondents stated that they, a family member, or a partner were not comfortable self-identifying with facility staff (Justice in Aging 2015).

Gradually, more and more LGBT-friendly housing units are being established. For example, Mary's House for Older Adults, Inc. (Mary's House) in Washington, D.C. has developed communal and affordable housing for LGBT older adults, and incorporates organized programs for independent LGBT individuals aged 60 and older. Mary's House presented at the first White House LGBT Elder Housing Summit in 2016, where staff discussed the positive benefits of communal living, a model that has been shown to decrease the social isolation that many LGBT individuals experience (Woody 2016). In addition, a website was launched by Services \& Advocacy for LGBT Elders (SAGE) to connect LGBT elders with the housing resources they need to make informed decisions and protect themselves from discrimination (SAGE 2015).

\section{Legislation and Policy}

LGBT older adults need protection from discrimination based on their gender identity and sexual orientation in living arrangements, work environments, and public accommodations at the federal, state, and local level (Tucker and Meier 2016; Veldhuis et al. 2017). Article 2 of the UDHR promises the right to Freedom from Discrimination (UDHR 1948). Public accommodations include government and private entities that provide services such as libraries, movie theaters, and shops.
According to Human Rights Watch, only 20 states and the District of Columbia currently prohibit discrimination on the basis of sexual orientation and gender identity in settings that involve public accommodations (https://www.hrc.org/statemaps/public-accomodations). More than half of the USA does not have statewide protections in work environments, housing, and public accommodations for the LGBT population (Fredriksen-Goldsen 2016). In 2015, SAGE worked with the US Department for Housing \& Urban Development (HUD) to declare a new directive to federally supported senior housing providers to prohibit discrimination against LGBT older adults and to issue a strong directive prohibiting discrimination against LGBT older adults in federally subsidized and insured housing (SAGE 2015). However, at the state level, only 21 states and the District of Columbia have laws that explicitly protect LGBT persons from housing discrimination (https://www.hrc.org/statemaps/public-accomodations).

\section{Older Americans Act (OAA)}

Passed in 1965, the OAA is the US primary law for funding and delivering social and nutrition programs to older adults and their caregivers. However, the OAA, a 2 billion dollar-ayear program, makes no mention of LGBT older adults (Choi and Meyer 2016; SAGE 2015). Many social justice advocates have proposed that older adults with HIV and LGBT older adults be included as a population of "greatest social need" in the updated OAA (Fredriksen-Goldsen and Espinoza 2015). SAGE is working to amend the OAA so LGBT older adults are specified as a population of "greatest social need" (SAGE 2015). The 2015 White House Conference on Aging (WHCOA), which takes place every decade and focuses on identifying and advancing actions to increase older Americans' quality of life, the Administration for Community Living and SAGE announced plans to meet with key stakeholders from state and local aging programs, as well as the LGBT community, to find ways to improve OAA outreach to LGBT older adults (WHCOA 2015).

\section{Affordable Care Act}

For decades, access to culturally sensitive and adequate health care was insufficient or negligible for many LGBT older adults (Witten 2016). That changed with the passage of the Affordable Care Act (ACA) in 2010, as federal nondiscrimination policies in healthcare services based on sexual orientation or gender identity were enforced (FredriksenGoldsen 2015). By prohibiting insurance companies from refusing coverage or increasing premiums due to an individual's gender identity or sexual orientation or a pre-existing condition like HIV (which disproportionately affects LGBT individuals), the ACA benefits many LGBT older adults. During 
the ACA's first enrollment period (October 2013-March 2014), however, many LGBT individuals disclosed not knowing the information necessary to understand how their states approached transgender issues, HIV coverage, and other concerns, and many of the statewide ACA outreach and enrollment organizations did not include LGBT communities. Studies showed that $34 \%$ of LGBT people, including $28 \%$ of people ages 50-64, were not insured when ACA's first open enrollment started (Fredriksen-Goldsen and Espinoza 2015). On the positive side, federal law could mandate marketplaces to include demographic data on LGBT individuals, helping to measure the extent to which LGBT older adults enroll in new health insurance options. Demographic data would also help identify where gaps in coverage are more prominent (Fredriksen-Goldsen and Espinoza 2015). Programs like SAGE's SAGE Care provide LGBT competency and aging training, national credentialing, and consulting for healthcare providers and seek to improve the healthcare sector by helping providers advertise their efforts to become LGBT-friendly, consequently supporting more of the LGBT community to obtain healthcare (SAGE 2015). Programs that may serve LGBT individuals need appropriate training to increase the general working knowledge of the LGBT community. As social workers, we are expected to be component providers so seeking training and professional development opportunities is critical to remain an ethical and competent social worker (NASW 2018).

\section{Recommendations}

To meet LGBT older adults' unique needs, policymakers and service providers must have access to current and improved data collection on this segment of the population. Service providers should incorporate questions regarding sexual orientation and gender identity by adding them to the demographics section of all surveys and forms. In addition, better data collection would provide information to federal and state level policymakers, who could then effectively distribute funding for aging services and programs and update the language in out-of-date laws and policies requiring data collection about LGBT individuals (LGBT Elder Initiative 2017).

\section{Need for High-Quality Data on Older LGBT Population}

In 2013, The National Health Interview Survey (NHIS), for the first time in its 57-year existence, measured the sexual orientation of the non-institutionalized adult population in the U.S. (Ward et al. 2014). The study enabled researchers and data users to analyze health-related behaviors, health status, and healthcare use among sexual minorities in the adult US population (Ward et al. 2014). However, gaps still remain in information regarding LGBT older adult health. Gathering quality information on
LGBT older adults' health and well-being is paramount to creating policy initiatives, promoting health equity, and achieving a better understanding of the scope of their health disparities. This could be achieved by designing questions for older adults regarding their sexuality and identity, sexual patterns, attraction, and romantic relationships, in addition to gender, including biological sex, and gender identity (Fredriksen-Goldsen and Espinoza 2015). Research needs to explore the forms of social marginalization and exclusion of LGBT older adults and identify the factors that positively and negatively affect healthcare equity. Consequently, information about sexual orientation and gender identity should be collected in the same way as other sociodemographic characteristics that affect health (e.g., race, age, ethnicity, income, gender, and education) are collected. Research should also examine the experiences from a larger sampling of LGBT individuals of different socioeconomic backgrounds to examine how these backgrounds influence health and healthcare choices (Fredriksen-Goldsen et al. 2014b).

\section{Need for Fair Access to Government Support Services}

On July 31, 2018, Senators Kamala Harris and Tom Carper introduced a bill (Census Equality Act) that would place questions about sexual orientation and gender identity on both the 2030 U.S. Census and the 2020 American Community Survey. The purpose of adding these populations to the census and survey, outside of upholding the basic tenets of human rights, enforcement of civil rights (Article 3 of the UDHR promises the right to Life, Liberty \& Personal Security (UDHR 1948)), and equal visibility, includes fair disbursement of government resources and services, and equal access to Medicaid, justice (Article 7 of the UDHR promises the right to Equality before the Law (UDHR 1948)), housing, and food support (Wang 2019). In a 2013 report by the Williams Institute, it was shown that the income levels of gay, lesbian and bisexual individuals more often fall below the federal poverty level than do the income levels of heterosexual individuals (Badgett et al. 2013). Consequently, obtaining a more accurate representation of the size and differences among this population offers the community not only a wider range of services, but also more specific and appropriate services. While this bill promises a good start to expanded data collection, it could use better delineation of current LGBTQ sexual orientation definitions. In its present state, the Census Equality Act defines "sexual orientation" to mean homosexuality, heterosexuality, or bisexuality. To date, this bill has not been passed (S.3314 - Census Equality Act 115th Congress 2017-2018).

\section{Outreach}

Studies show that some LGBT older adults are uncomfortable seeking out alcohol and substance abuse programs, as well as 
veterans' and assisted housing services due to the discrimination and stigmatization they often face (Fredriksen-Goldsen et al. 2013). It is essential that more training for service providers be facilitated, in order to create a safe environment in which LGBT individuals can seek assistance, and to ensure ongoing, valuable, and competent care (Fredriksen-Goldsen et al. 2013). Healthcare providers must implement training that reduces bias and discrimination and offers culturallycompetent care to LGBT older adults, including those who are vulnerable and at-risk (Fredriksen-Goldsen 2016). Partnerships between healthcare and aging services are essential to ensure comprehensive health and aging services are accessible to LGBT older adults. Projects funded by the OAA must target programs and services that benefit the needs of LGBT older adults and their caregivers (FredriksenGoldsen 2015).

It has been recommended that LGBT older adults work with others of all ages to serve on organizational boards and committees to improve organizations' abilities to implement culturally responsive health, aging, and cross-generational services (Fredriksen-Goldsen 2016). Educational outreach efforts by LGBT and aging organizations need to focus on making LGBT older adults aware of their rights under current laws and regulation (Fredriksen-Goldsen 2016). In addition, LGBT and aging organizations need to create programs to reduce loneliness and isolation. For example, Generations: Aging with Pride is one of the first LGBT organizations to focus on creating cross-generational opportunities and analyzing evidence-based solutions to building stronger communities and addressing aging concerns among LGBT individuals (Fredriksen-Goldsen 2016).

Comprehending the social, structural, and institutional factors that contribute to gaps in LGBT older adults' access to healthcare and health outcomes is a component of social justice (Emlet 2016). Comprehensive public policies are necessary for LGBT individuals to gain health equity (FredriksenGoldsen and Espinoza 2015). There must be a complete and thorough knowledge-base of the LGBT community to evaluate, develop, and implement policies that will ensure health equity for all LGBT older adults (Fredriksen-Goldsen and Espinoza 2015).

\section{Human Rights and Social Work}

The Universal Declaration of Human Rights originated in 1948 to establish basic rights that every human being is entitled to at birth (United Nations 1948). The United States was one of the first countries to sign, yet only ratify through the International Convention on Civil and Political Rights up to, first, Article 16, then up to Article 22, in order to remain consistent with the US Constitution (History of the Document 2018; Parsons 2018). Articles 23 through 30 (those not yet ratified by the United States) include the rights to: Desirable Work and to Join Trade Unions, Rest and Leisure, Adequate Living Standard, Education, Participate in the Cultural Life of Community, A Social Order that Articulates this Document, Community Duties Essential to Free and Full Development, Freedom from State or Personal Interference in the Above Rights (UDHR 1948).

LGBT individuals were not well-known in 1948, subsequently, the authors did not include sexual orientation or gender identity as a protected class. However, UDHR Article Two, which declares the right to Freedom from Discrimination, states that everyone is entitled to all of the rights listed in the UDHR regardless of distinction of any kind, including "sex" or "other class" (United Nations 1948). Yet, as the LGBT community has grown and society progressed, the U.S. has failed to provide equal and non-discriminatory protection to this class because of their sexuality. The now older LGBT community still lacks legal protection from the U.S. government and continues to face numerous forms of discrimination. It could be argued that, by excluding the LGBT community from protection against all forms of discrimination and refusing to legally recognize their status as a protected class, the USA is in violation of Article Two, as well as several other UDHR articles and their successive emergent treaties. Many US administrations have taken the position that these human rights treaties are "soft law," and therefore simply future goals, rather than inalienable rights. The USA "is the only developed country to insist that, in effect, its government has no obligation to safeguard the rights of citizens to jobs, housing, education and an adequate standard of living" (Parsons 2018, paragraph 6). The goal of implementing protective policy for older LGBT adults is to provide legal protections against all forms of discrimination and to enforce all human rights as outlined in the Universal Declaration of Human Rights.

\section{Social Workers' Roles in Advancing Rights of LGBT Elders}

It is the role of the social worker to advance social justice by advocating for and empowering the older LGBT community to attain and maintain equal rights as equal citizens. The United Nations (UN) emphasizes a human rights-based approach to addressing these social inequalities (United Nations 1948). Similar to social work values, the human rights-based approach is founded on the key elements of human dignity, non-discrimination, participation, transparency, and accountability (Androff 2016). The establishment of any policy or practice should adhere to these key elements.

Human Dignity A human rights framework with a strengthsbased approach should be utilized to affect change and advance social justice. Rights-holders need to be empowered and educated in order to participate in the process of legislating and implementing change. 
Non-discrimination Social workers must also identify and challenge individuals and systems that encourage discrimination and oppression against the older LGBT community. Through individual, community, and systematic engagement, social workers can comprehensively assess the needs of the older LGBT community and provide recommendations and support for policy and best practices.

Participation Members of the older LGBT community should actively engage in shaping policy and practices that are non-discriminatory and that support human dignity (LGBT Elder Initiative 2017). As written in the social work competencies, practice should be researchinformed and evidence-based (National Association of Social Workers 2017). Likewise, proposed policy needs to be practice and research-informed to be successful. To achieve this, social workers must engage, interact, and share resources with the individuals, communities, systems, and organizations that are impacted by the issues of older LGBT adults.

Accountability A systematic review of anti-gay bias among social work professionals and social work students found that while bias may be low, social workers are often ill-prepared to address the needs of LGBT clients (Chonody and Smith 2013). Yet, cultural competence, human dignity, and social justice are central tenets of the social work professional code of ethics (NASW 2018). Therefore, continuing education in professional programs and post-graduation are needed so that social workers can appropriately support LGBT older adults. This training should include approaches such as Gay Affirmative Practice (GAP) and Trans Affirmative Practice (Burdge 2007; Crisp 2006).

\section{Conclusions}

Social workers have an ethical obligation to advance the rights of LGBT elders, in accordance with our professional Code of Ethics (NASW 2018). First, we must respect their human rights and dignity as individuals. Second, we must ensure that all agencies, as well as city, state, and federal governments have non-discrimination policies that include sexual orientation, gender identity and expression. Third, LGBT elders should be invited and encouraged to participate in identifying and improving environments and policies that impact their well-being. Finally, social workers must be held accountable for their own competence in that they should receive and deliver sufficient training in matters related to sexual orientation, gender identity and expression. Social workers must ensure that they can work competently with LGBT individuals and to not cause harm.

\section{References}

Androff, D. (2016). Practicing rights. New York: Routledge.

Auldridge, A., \& Espinoza, R. (2013). Health equity and LGBT Elders of color: recommendations for policy and practice. SAGE (Services and Advocacy for GLBT Elders). https://static1.squarespace.com/ static/566c7f0c2399a3bdabb57553/t/566caf95841abafcc8e8018d/ 1449963413451/2013-SAGE-Health-Equity-and-LGBTEldersRecommendations-for-Policy-and-Practice.pdf. Accessed 1 May 2019.

Badgett, M. V. L., Durso, L., \& Schneebaum, A., (2013). "New Patterns of Poverty in the Lesbian, Gay, and Bisexual Community." Williams Institute. Retrieved from: http://williamsinstitute.law.ucla.edu/wpcontent/uploads/LGB-Poverty-Update-Jun-2013.pdf. Accessed 1 May 2019.

Bonifas, R. P. (2016). The prevalence of Elder bullying and impact on LGBT elders. In D. A. Harley \& P. B. Teaster (Eds.), Handbook of LGBT elders: An interdisciplinary approach to principles, practices, and policies. Dordrecht: Springer. https://doi.org/10.1007/978-3319-03623-6.

Burdge, B. J. (2007). Bending Gender, Ending Gender: Theoretical Foundations for Social Work Practice with the Transgender Community. Social Work, 52(3), 243-250. https://doi.org/10.1093/ $\mathrm{sw} / 52.3 .243$.

Cartwright, C., Hughes, M., \& Lienert, T. (2012). End-of-life care for gay, lesbian, bisexual and transgender people. Culture, Health \& Sexuality, 14(5), 537-548.

Choi, S. K., \& Meyer, I. H. (2016). LGBT aging: A review of research findings, needs, and policy implications. Los Angeles: The Williams Institute.

Chonody, J. M., \& Smith, K. S. (2013). The state of the social work profession: A systematic review of the literature on antigay bias. Journal of Gay \& Lesbian Social Services, 25(3), 326-361.

Christensen, K., Doblhammer, G., Rau, R., \& Vaupel, J. W. (2009). Ageing populations: The challenges ahead. The Lancet, 374(9696), 1196-1208.

Committee on Lesbian, Gay, Bisexual, and Transgender Health Issues and Research Gaps and Opportunities; Board on the Health of Select Populations; Institute of Medicine. (2011). The health of lesbian, gay, bisexual, and transgender people: Building a foundation for better understanding. Washington, DC: The National Academic Press.

Crisp, C. (2006). Correlates of homophobia and use of gay affirmative practice among social workers. Journal of Human Behavior in the Social Environment, 14, 119-143.

Department of Health and Human Services (2015). Retrieved from https://www.medicaid.gov/federal-policy-guidance/downloads/sho15-005.pdf. Accessed 1 May 2019.

Emlet, C. A. (2016). Social, economic, and health disparities among LGBT older adults. Journal of American Society on Aging., 40, $16-22$.

Erdley, S. D., Anklam, D. D., \& Reardon, C. C. (2014). Breaking barriers and building bridges: Understanding the pervasive needs of older LGBT adults and the value of social work in health care. Journal of Gerontological Social Work, 57(2-4), 362-385.

Fredriksen-Goldsen, K. I. (2015). Promoting health equity among LGBT mid-life and older adults. Journal of the American Society on Aging, $38,86-92$.

Fredriksen-Goldsen, K. I. (2016). The future of LGBT + aging: A blueprint for action in services, policies, and research. Journal of the American Society on Aging. Generations, 40(2), 6-15.

Fredriksen-Goldsen, K., \& Espinoza, R. (2015). Time for transformation: Public policy must change to achieve health equity for LGBT older adults. Journal of the American Society on Aging, 38, 4; 96-4;104. 
Fredriksen-Goldsen, K. I., Emlet, C. A., Kim, H. J., Muraco, A., Erosheva, E. A., Goldsen, J., \& Hoy-Ellis, C. P. (2012). The physical and mental health of lesbian, gay male, and bisexual (LGB) older adults: The role of key health indicators and risk and protective factors. The Gerontologist, 53(4), 664-675.

Fredriksen-Goldsen, K. I., Kim, H.-J., Hoy-Ellis, C. P., Goldsen, J., Jensen, D., Adelman, M., Costa, L. M., \& De Vries, B. (2013). Addressing the needs of LGBT older adults in San Francisco: Recommendations for the future. Seattle: Institute for Multigenerational Health, University of Washington.

Fredriksen-Goldsen, K. I., Kim, H.-Y., Shiu, C., Goldsen, J., \& Emlet, C. A. (2014a). Successful aging among LGBT older adults: Physical and mental health-related quality of life by age group. The Gerontologist, 1-15.

Fredriksen-Goldsen, K. I., Lehavot, K., Walters, K. L., Yanj, J., HoyEllis, C. P., \& Muraco, A. (2014b). The health equity promotion model: Reconceptualization of lesbian, gay, bisexual, and transgender (LGBT) health disparities. American Journal of Research of Orthopsychiatry, 84(6), 653-663.

Gonzales, G., Przedworski, J., \& Henning-Smith, C. (2016). Comparison of health and health risk factors between lesbian, gay, and bisexual adults and heterosexual adults in the United States: Results from the National Health Interview Survey. JAMA Internal Medicine, 176(9), 1344-1351. https://doi.org/10.1001/jamainternmed.2016.3432.

Harley, D. A. (2016). African-American and black LGBT elders. In D. A. Harley \& P. B. Teaster (Eds.), Handbook of LGBT elders: An interdisciplinary approach to principles, practices, and policies. Dordrecht: Springer. https://doi.org/10.1007/978-3-319-03623-6.

Hash, K. M., \& Netting, F. E. (2007). Long-term planning and decisionmaking among midlife and older gay men and lesbians. Journal of Social Work in End-of-Life \& Palliative Care, 3(2), 59-77.

Hatzenbuehler, M. L., Bellatorre, A., Lee, Y., Finch, B. K., Muennig, P., \& Fiscella, K. (2014). Structural stigma and all-cause mortality in sexual minority populations. Social Science \& Medicine, 103, 33-41.

Healthy People (2020). Retrieved from https:/www.healthypeople.gov/ node/5840. Accessed 1 May 2019.

Herman, J. (2016). LGB within the T: Sexual orientation in the National Transgender Discrimination Survey and implications for public policy. In Y. M.-S. Miguel \& S. Tobias (Eds.), Trans studies: The challenge to hetero/homo normativities. Rutgers: Rutgers University Press.

History of the Document (2018). Retrieved from http://www.un.org/en/ sections/universal-declaration/history-document/index.html. Accessed 1 May 2019.

Justice in Aging (2015). LGBT older adults in long-term care facilities: Stories from the field. Justice in aging: Fighting senior poverty through law. Retrieved from https://www.justiceinaging.org/lgbtolder-adults-in-long-term-care-facilities-stories-from-the-field- $2 /$. Accessed 1 May 2019.

Kim, H.-Y., Fredriksen-Goldsen, K. I., Bryan, A. E. B., \& Muraco, A. (2017). Social network types and mental health among LGBT older adults. The Gerontologist, 57, 1; 84-1; 94.

Lennon-Dearing, R., \& Delavega, E. (2015). Policies discriminatory of the LGBT community: Do social workers endorse respect for the NASW code of ethics? Journal of Gay \& Lesbian Social Services, 27(4), 412-435. https://doi.org/10.1080/10538720.2015.1087266.

LGBT Elder Initiative (2017). Policy positions. The LGBT Elder Initiative. Retrieved from https://gbtelderinitiative.org/2019/02/07/ actively-advocating-for-your-care/. Accessed 1 May 2019.

National Association of Social Workers (2017). Code of ethics of the National Association of Social Workers. Washington, DC: NASW Press.

National Association of Social Workers. (2018). Code of ethics of the National Association of Social Workers. Washington, DC: NASW Press.

Obergefell v. Hodges, 576 U.S. (2015). Retrieved from https://www. supremecourt.gov/opinions/14pdf/14-556_3204.pdf. Accessed 1 Apr 2019.
Parsons, A. (2018). As the Universal Declaration of Human Rights turns 70 , it's time to resurrect its vision of global sharing and justice. Retrieved from https://www.sharing.org/information-centre/ articles/universal-declaration-human-rights-turns-70-its-timeresurrectits. Accessed 1 Apr 2019.

Paula, C. E. A., da Silva, A. P., \& Bittar, C. M. L. (2017). Legislative vulnerability of minority groups. Ciencia \& Saude Coletiva, 22(12), 3841-3848. https://doi.org/10.1590/1413-812320172212. 24842017.

Russell, G.M. \& Bohan, J.S. (2005). The gay generation gap: Communicating across the LGBT generation divide. Angles Policy Journal of The Institute for Gay and Lesbian Strategic Studies (IGLSS), 8(1). http://drglendarussell.com/wpcontent/uploads/2013/ 05/Angles_GayGenerations.pdf. Accessed 1 May 2019.

Services and Advocacy for Gay, Lesbian, Bisexual \& Transgender Elders (SAGE) (2015). Sage: Annual report 2015. Sage.

Sokan, A. E., \& Teaster, P. B. (2016). An overview of aging and mistreatment of LGBT elders. In D. A. Harley \& P. B. Teaster (Eds.), Handbook of LGBT elders: An interdisciplinary approach to principles, practices, and policies. Dordrecht: Springer. https://doi.org/ 10.1007/978-3-319-03623-6.

S.3314 - Census Equality Act 115th Congress (2017-2018). Retrieved from https://www.congress.gov/bill/115th-congress/senate-bill/ 3314/text. Accessed 1 Apr 2019.

Thomeer, M. B., Paine, E. A., \& Bryant, C. (2018). Lesbian, gay, bisexual, and transgender families and health. Sociology Compass, 12(1), e12552. https://doi.org/10.1111/soc4.12552.

Tucker, J. D., \& Meier, B. M. (2016). Bigotry, bills, and medicine: Lessons from the USA. The Lancet, 388(10046), 756-757.

United Nations. (1948). Universal Declaration of Human Rights. https:// www.ohchr.org/EN/UDHR/Documents/UDHR_Translations/eng. pdf. Accessed 1 May 2019.

United States v. Windsor, 570 U.S. 744 (2013). Retrieved from https:// www.supremecourt.gov/opinions/12pdf/12-307_6j37.pdf. Accessed 1 May 2019.

Veldhuis, C. B., Drabble, L., Riggle, E. D. B., Wootton, A. R., \& Hughes, T. L. (2017). "We won't go back into the closet now without one hell of a fight": Effects of the 2016 presidential election on sexual minority women's and gender minorities' stigma-related concerns. Sexuality Research and Social Policy, 15(1), 12-24.

Wang, H. (2019). Senate bill to require sexual orientation, gender identity data by 2030 census. Retrieved from https://www.npr.org/2018/07/ 31/634243854/senate-bill-to-require-sexual-orientation-genderidentity-data-by-2030-census. Accessed 1 Apr 2019.

Ward, B. W., Dahlhamer, J. M., Galinsky, A. M., \& Joestl, S. S. (2014). Sexual orientation and health among U.S. adults: National Health Interview Survey, 2013. National Health Statistics Report., 77, 1-12.

White house conference on aging: Final report (2015). Retrieved from http://www.whitehouseconferenceonaging.gov/2015-WHCOAFinal-Report.pdf. Accessed 1 May 2019.

Witten, T. M. (2016). The intersectional challenges of aging and of being a gender non-conforming adult. The Journal of the American Society on Aging, 40, 63-70.

Woody, I. (2016). Mary's house: An LGBT/SGL-friendly alternative environment for older adults. Journal of the American Society on Aging, 40, 108-109.

Publisher's Note Springer Nature remains neutral with regard to jurisdictional claims in published maps and institutional affiliations. 